\title{
Childhood B Acute Lymphoblastic Leukemia with $\mathrm{t}(9 ; 22)(\mathrm{q} 34.1 ; \mathrm{q} 11.2)$; BCR- ABL1
}

National Cancer Institute

\section{Source}

National Cancer Institute. Childhood B Acute Lymphoblastic Leukemia with t(9;22)

(q34.1;911.2); BCR-ABL1. NCI Thesaurus. Code C68659.

A B-cell acute leukemia occurring in childhood. It is characterized by the presence of lymphoblasts that carry a translocation between the BCR gene on chromosome 22 and the ABL1 gene on chromosome 9. It results in the production of the p190 kd or p210 kd fusion protein. It has an unfavorable clinical outcome. 